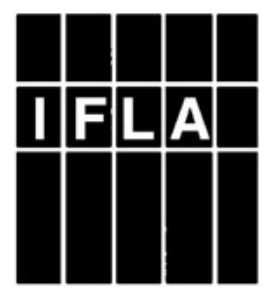




\section{IFLA Publications}

\section{Edited by}

Michael Heaney

International Federation of Library Associations and Institutions

Fédération Internationale des Associations de Bibliothécaires et des Bibliothèques

Internationaler Verband der bibliothekarischen Vereine und Institutionen

Международная Федерация Библиотечных Ассоциаций и Учреждений

Federación Internacional de Asociaciones de Bibliotecarios y Bibliotecas

国际图书馆协会与机构联合会

الاتحاد الاولي لجمعيات ومؤسسات المكتبات

\section{Volume 175}




\section{Space and Collections Earning their Keep}

Transformation, Technologies, Retooling

Edited by Joseph Hafner and Diane Koen

\section{DE GRUYTER}

SAUR 
ISBN 978-3-11-046197-8

e-ISBN (PDF) 978-3-11-046420-7

e-ISBN (EPUB) 978-3-11-046205-0

ISSN 0344-6891

\section{Library of Congress Cataloging-in-Publication Data}

A CIP catalog record for this book has been applied for at the Library of Congress.

\section{Bibliografische Information der Deutschen Nationalbibliothek}

The Deutsche Nationalbibliothek lists this publication in the Deutsche Nationalbibliografie; detailed bibliographic data is available on the internet at http://dnb.dnb.de.

(C) 2016 Walter de Gruyter GmbH, Berlin/Boston

Cover Image: McGill University Library. Rendering by Shepley Bulfinch

Typesetting: Dr Rainer Ostermann, München

Printing and binding: CPI books $\mathrm{GmbH}$, Leck

(2) Printed on acid-free paper

Printed in Germany

www.degruyter.com 